\title{
Takayasu arteritis
}

INSERM

\section{Source}

INSERM. (1999). Orphanet: an online rare disease and orphan drug data base. Takayasu arteritis. ORPHA:3287

A rare predominantly large-vessel vasculitis that is characterized by affected aorta and its major branches, but also other large vessels, causing stenosis, occlusion, or aneurysm. 